\title{
Lightning Mapping Observations of Downward Lightning Flashes To Wind Turbines
}

\author{
J. Montanyà, O. van der Velde, A.Domingo-Dalmau \\ Department of Electrical Engineering \\ Universitat Politècnica de Catalunya, UPC \\ Terrassa (Barcelona), Spain \\ montanya@ee.upc.edu
}

\begin{abstract}
Negative downward leaders that produced lightning strokes to wind turbines are identified by means of the Lightning Mapping Array data of the Ebro Valley Laboratory (NE Spain). Four cases are analyzed together with weather radar imagery. All flashes hitting wind turbines were originated in small convective cells with moderate development. Notwithstanding the moderate convection, all cases occurred under what can be called "out of season conditions", where the "charging zone" is located closer to the ground and may favour downward leaders to tall structures. Cloud charge structures showed negative region from $3 \mathrm{~km}$ to more than $5 \mathrm{~km}$ with a low positive charge below (not always detectable).
\end{abstract}

Keywords-lightning mapping array, wind turbines, weather radar

\section{INTRODUCTION}

Multi-megawatt wind turbines are tall structures prone to be hit by lightning. In addition, they are peculiar tall objects with rotating blades made of conductive composite material, usually, in continuous rotation. As these distinctive features difficult their protection against lightning, the interactions with lightning deserves in-depth analysis.

In the recent years, the use of high resolution lightning mapping systems and high-speed video provided relevant information about the lightning environment related to wind turbines. The first lightning mapping array (LMA) flashes initiated by wind turbines were presented not long ago in [1] and [2]. Additionally, in these references, long lasting corona activities from rotatory parts of wind turbines were reported. These particular corona emissions have been investigated later by [3] confirming that corona discharges from wind turbines can be produced even with low ambient electric fields.

Most of the optical observations of lightning to wind turbines show upward lightning flashes (e.g. [1] and [4]). In this work we present some examples of downward flashes where wind turbines are involved. We use LMA, cloud-to-ground lightning data and Doppler weather radar. Our objective is to identify the common features of the thunderstorms that produced flashes striking wind turbines.

\author{
N. Pineda, O. Argemí, A.Salvador \\ Remote Sensing Unit \\ Servei Meteorològic de Catalunya \\ Barcelona, Spain
}

\section{DATA}

In the summer of 2011 the Ebro 3D Lightning Mapping Array (ELMA) was installed on the north-east coast of Spain (Fig. 1). The ELMA maps radio emissions of lightning channels in three dimensions by the time-of-arrival (TOA) technique in the very high frequency (VHF) range (e.g. [5]) from an array of VHF remote sensors. Several large wind farms are present within the range of the ELMA. This array has sensor-to-sensor distances of only 5 to 20 kilometers and the wind farms of interest are located less than $12 \mathrm{~km}$ from the network center.

Cloud-to-ground strokes are reported by the LINET VLF/LF lightning detection network [6]. 'La Miranda' radar (LMI) more described in [7], is a C-band radar of the Meteorological Service of Catalonia (SMC) about $40 \mathrm{~km}$ north of the Ebro Delta provided reflectivity fields of the thunderstorms causing the lightning that affected the wind turbines.

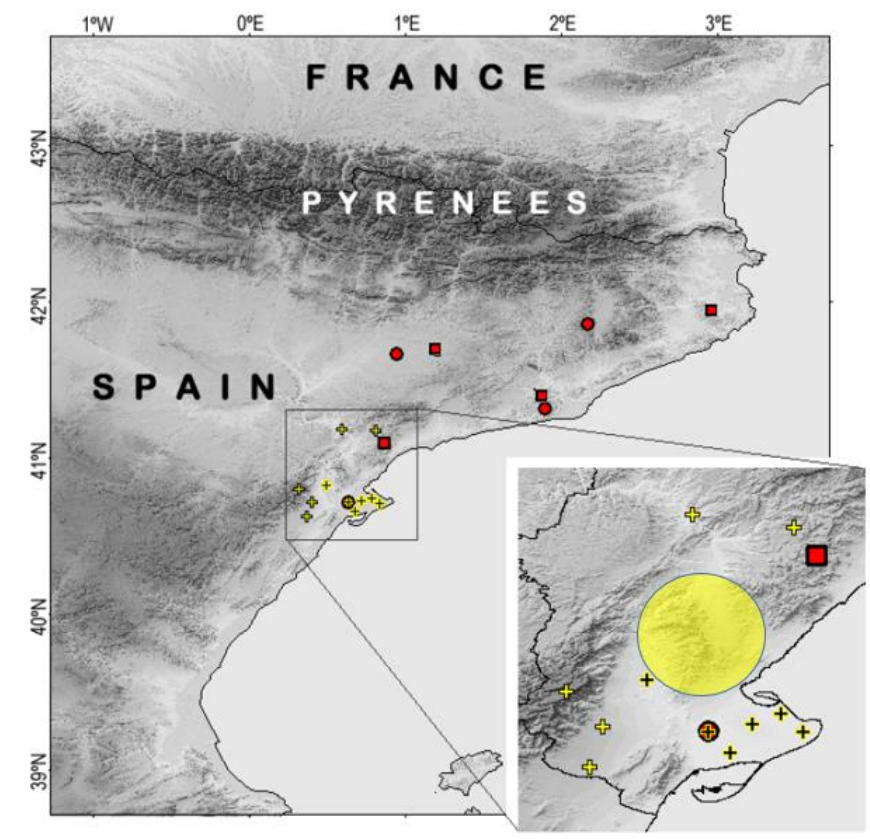

Figure 1. Map showing the location of the ELMA sensors (crosses) and weather radars (squares). Yellow shadowed area corresponds to the location of the wind farms. 


\section{METHODOLOGY}

Episodes with lightning flashes involving wind turbines were primarily identified by means of LINET cloud-to-ground (CG) data. Clusters of CG are often observed around tall structures [6] and the area with wind farms were monitored looking for clusters of strokes around wind turbines within a buffer of $\sim 150 \mathrm{~m}$. For these identified strokes ELMA data was inspected. The ELMA provides $3 \mathrm{D}$ view of the intracloud detected sources. The located sources are mainly coming from negative leaders moving through regions of positively charged cloud particles, but weaker sources from positive leader traces inside the negative charge region are often detected as well (likely caused by negative recoil leaders, see for example [8]). In order to distinguish negative and positive leader development the 2D time-distance plot developed in [9] was used. To be sure that the events involved negative downward leaders, we selected those cases where the leader to ground can be identified. Unfortunately, no optical records were available for the analyzed events.

\section{OBSERVATIONS}

On the following we present four representative cases.

\section{A. Case \#1 20111120 [04:37 UTC]}

The LMA plot of this flash is shown in Fig. 2. The flash started just above a wind turbine with a fast negative downward leader originated at $\sim 3 \mathrm{~km}$ altitude producing two strokes involving wind turbines. The first stroke produced a current of $-98 \mathrm{kA}$ and involved the turbines at highest altitude ( $625 \mathrm{~m})$ of the area. The second stroke of $-7 \mathrm{kA}$ occurred $23 \mathrm{~ms}$ after. The flash shows low altitude positive leader development with negative leader activity above. No leader activity was observed above $6 \mathrm{~km}$.

a)

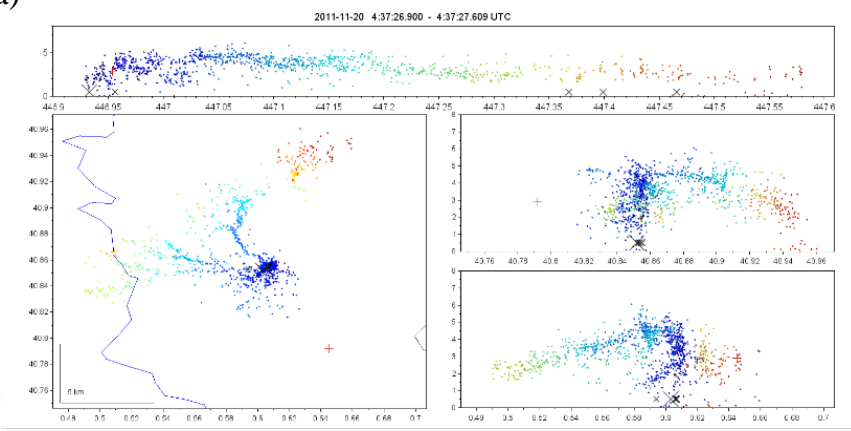

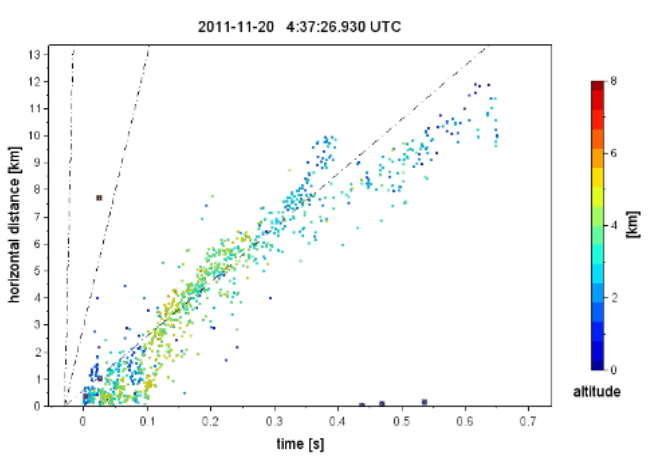

Figure 2. Case \#1: a) LMA views of the detected sources. Upper graph corresponds to height vs. time and under it the top (LAT vs. LON) and side views (LAT and LON vs. height).

The radar image, which corresponds to the maximum reflectivity product $\left(\mathrm{dBZ}_{\max }\right)$ shows that the flash started on a small convective core with reflectivity within 35-45 dBZ (Fig. $3)$. The in-cloud leaders progressed towards the trailing stratiform area. The Top-35 (height reached by $35 \mathrm{dBZ}$ ) was aroud $7.0 \mathrm{~km}$ throughout the thunderstorm life-cycle.
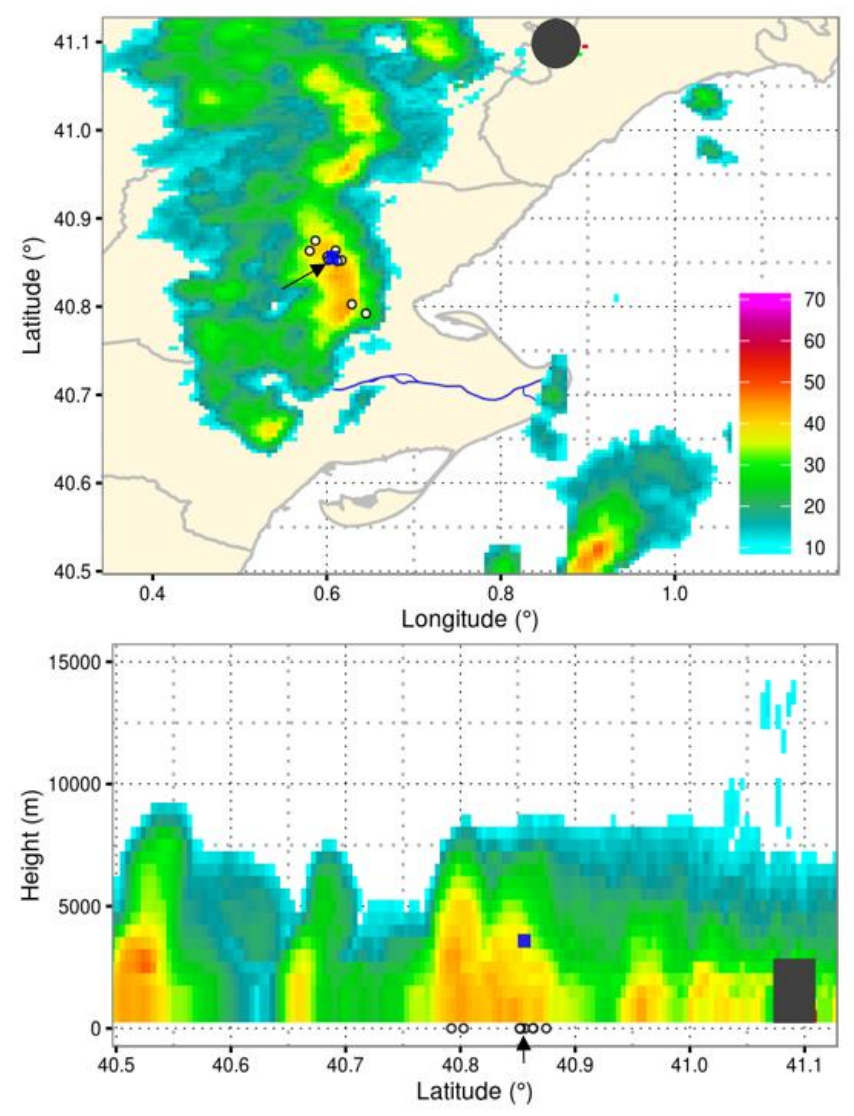

Figure 3. Maximum radar reflectivity (in dBZ) plot for case \#1. The blue square corresponds to the LMA initial point (intracloud breakdown). White dots are the CG LINET strokes. Arrow points to the wind turbines. In grey, the radar location. 


\section{B. Case \#2 20111120 [04:45 UTC]}

This flash affected the same turbine as in the case \#1 but $~ 8$ minutes later. This flash is shown in Fig. 4. The time distance plot in Fig. 4 reveals the presence of positive leaders at altitudes between $3-5 \mathrm{~km}$ and negative leaders developing to ground and at altitudes $2-3 \mathrm{~km}$. These leaders indicate a negative charge region at $3-5 \mathrm{~km}$ and some positive charge below. At $\sim 324.9 \mathrm{~s}$ (Fig. 4a) a negative leader progressed to ground and produced three strokes of $-17 \mathrm{kA},-11 \mathrm{kA}$ and $-11 \mathrm{kA}$. About $300 \mathrm{~ms}$ after, a negative cloud leader just above the CG locations travelled outwards to about $10 \mathrm{~km}$ at low levels.

a)

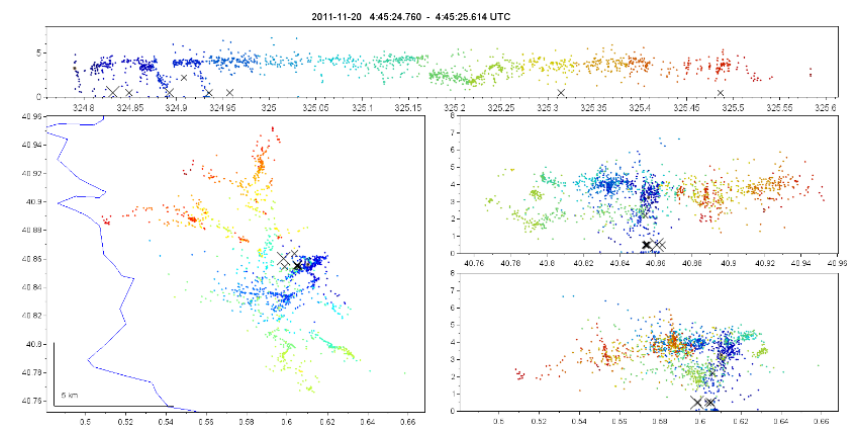

b)

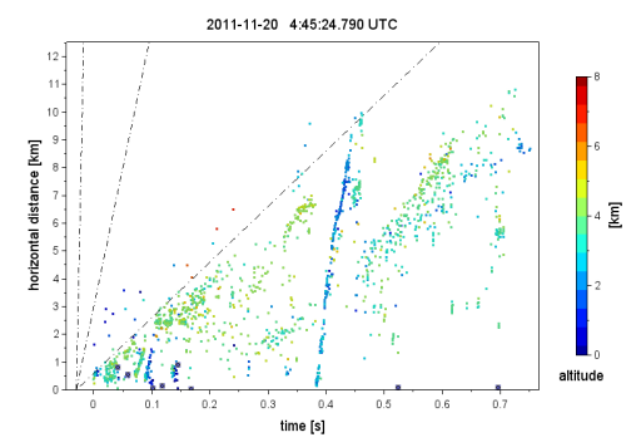

Figure 4. Case \#2: a) LMA flash and b) time vs. distance plot.

Regarding the radar reflectivity field, this flash was originated in the same thunderstorm cell as case \#1, eight minutes later, in similar conditions as the previous case study. The temperature at the altitude of $700 \mathrm{hPa}$ was $-4^{\circ} \mathrm{C}$ indicating that this case cannot be classified as winter lightning assuming the criteria in [10].

\section{Case \#3: 20121117 [17:34 UTC]}

This case (Fig. 5) corresponds to a complex flash originated about $50 \mathrm{~km}$ away from the involved wind turbine. Before striking the turbine, at $\mathrm{t}=264.34 \mathrm{~s}$ (Fig. $5 \mathrm{a}$ ), an intense $+\mathrm{CG}$ stroke (+52 kA) followed by continuing current $(1900 \mathrm{C} \cdot \mathrm{km})$ that triggered a sprite (see [11]) located at about $13 \mathrm{~km}$. After that, a new breakdown occurred close to the turbine where suddenly a negative leader progressed towards the turbine $(t=264.6 \mathrm{~s}$ in Fig. 6a) producing 9 strokes.

The time vs. distance plot in Fig. 5 b clearly shows a negative leader progressing from about $50 \mathrm{~km}$ passing $5 \mathrm{~km}$ close to the turbine location. After the negative leader had passed, positive breakdown occurred and suddenly a negative leader was directed towards a wind turbine. The leader sequence suggest that the first leader development related to the intense +CG flash initiated new leader breakdown at the wind turbine area.

The radar image in Fig. 6 shows the negative leader starting at the bottom of the image, in the border of a convective cell with maximum reflectivity around $45 \mathrm{dBZ}$, but the wind turbine hit by lightning is under a stratriform area with lower reflectivity, not reaching the $30 \mathrm{dBZ}$.

a)

b)
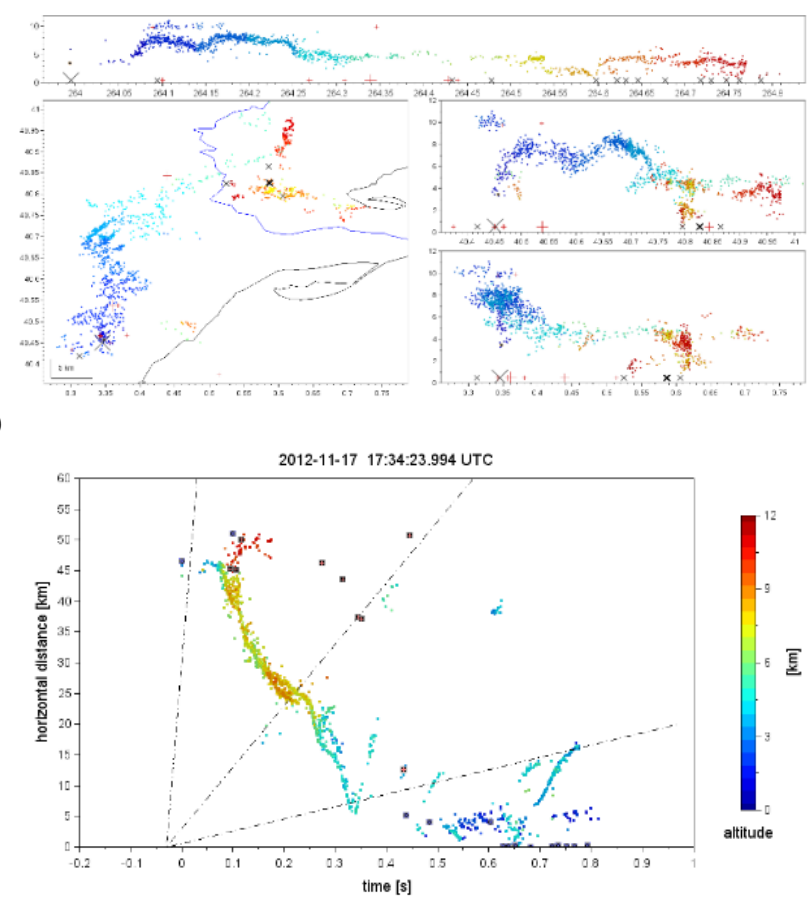

Figure 5. Case \#3: a) LMA flash and b) time vs. distance plot. 
Preprint of the Int. Conf. on Lightning Protection (ICLP 2016)
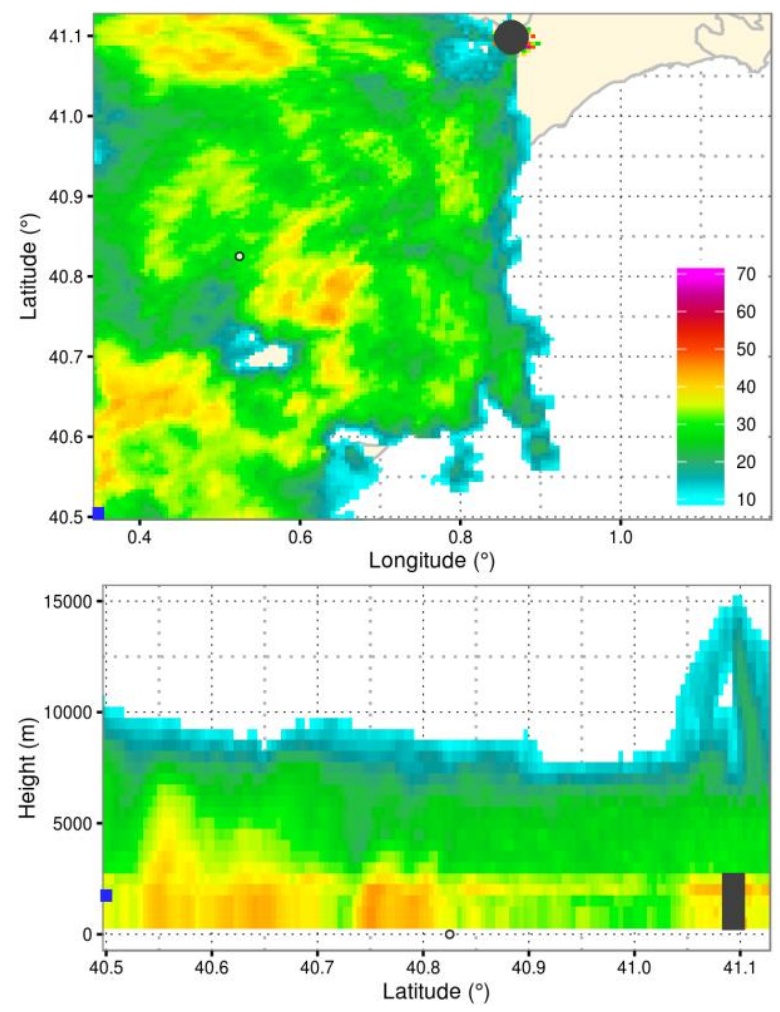

Figure 6. Analogous to Fig 3, but for for Case \#3 at 17:36 UT.

The radio sounding of 1800 UTC showed a temperature of $-3{ }^{\circ} \mathrm{C}$ at $700 \mathrm{hPa}$, so this case cannot be classified as winter lightning according [10].

\section{Case \#4: 20120403}

According to Fig. 7, leader activity kept below $6 \mathrm{~km}$ with remarkable positive leader development (different from case \#3). A negative leader to ground started at the beginning of the flash and ended with a $-18 \mathrm{kA}$ stroke to a turbine located at the highest hill ( $640 \mathrm{~m})$ of the area.

a)

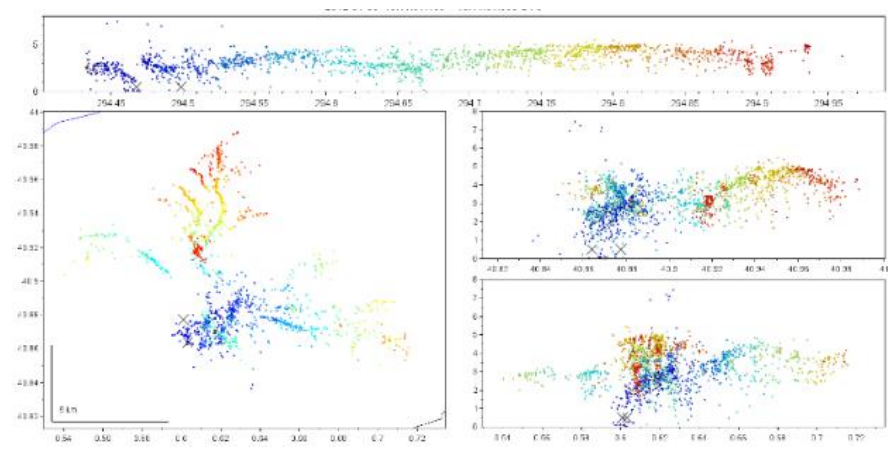

b)

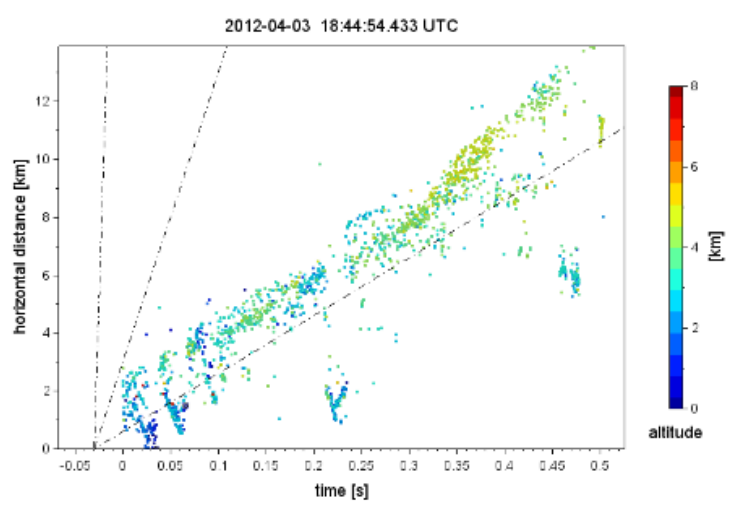

Figure 7. Case \#4: a) LMA flash and b) time vs. distance plot.

Regarding radar imagery, here the leader initiates in the rear edge of a convective cell and hits a turbine which is under the same cell. Compared to precedent cases, maximum reflectivity is slightly higher, but the vertical development is rather similar, with the Top-35 reaching 6.0 to $7.0 \mathrm{~km}$. The radio sounding at 1800 UTC revealed a temperature of $-4{ }^{\circ} \mathrm{C}$ at $700 \mathrm{hPa}$ which is similar to the previous cases.

\section{DISCUSSION AND CONCLUSIONS}

In all the four cases the highest wind turbines at the area (farm or hills) were the ones affected by negative downward leaders. In the LMA data we can distinguish a negative leader from a low level of the cloud progressing towards the turbine. In all the cases the return strokes currents were of negative polarity.

Significant charging allowing lighting production occurs only where graupel, ice crystals and supercooled droplets coexist. This region is referred to as the "charging zone" and its vertical extent is limited [12]. The upper boundary of the charging zone typically lies between the $-15^{\circ} \mathrm{C}$ and $-30^{\circ} \mathrm{C}$ isotherms. As a result of this dependence of the electrification processes on temperature, cloud charges are located closer to the ground in winter. 

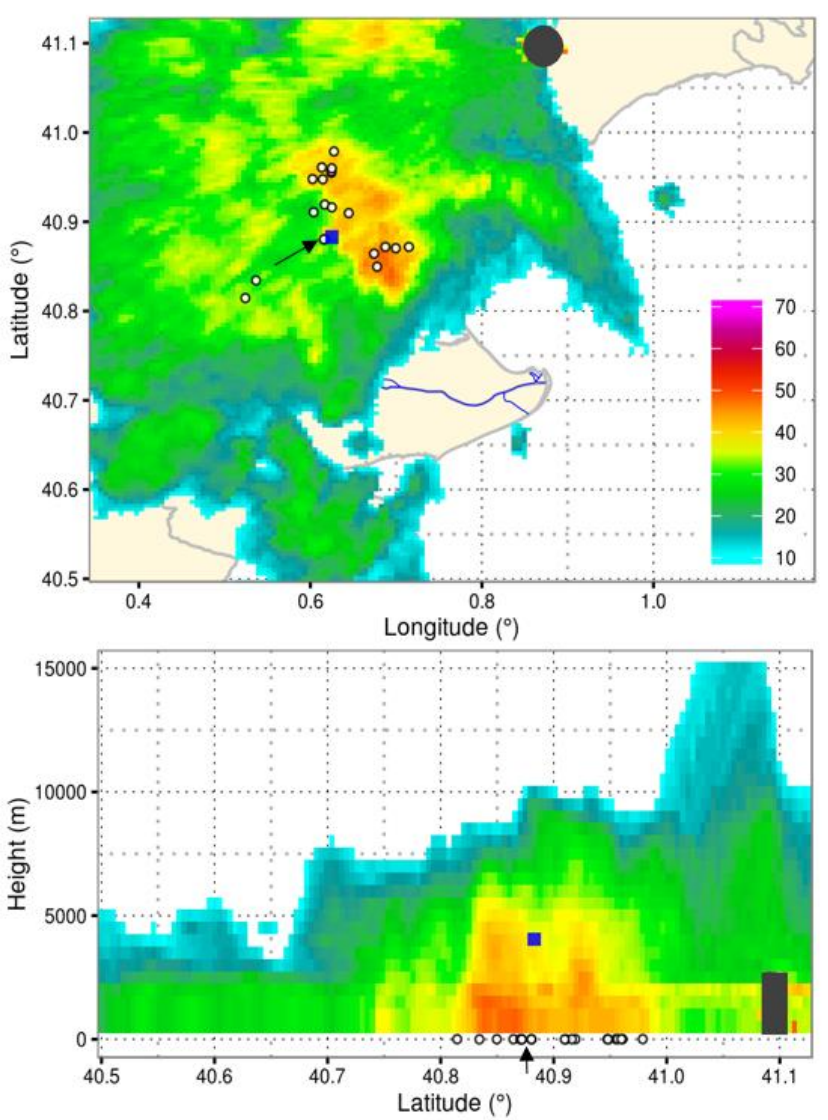

Figure 8. Analogous to Fig 3, but for Case \#4 at 18:42 UT.

The tropopause is found between 10 and $15 \mathrm{~km}$ at midlatitudes in summer but can descend below $10 \mathrm{~km}$ in winter, limiting the vertical extent of convection [12]. Climatology from the closest sounding station (Barcelona, $250 \mathrm{~km} \mathrm{NE}$ of the region of study) of the last 15 years shows the tropopause moving around $12.5-13.0 \mathrm{~km}$ in summer months, and between 10.5 and $11.5 \mathrm{~km}$ from December to April.

Focusing on the case study, the three analysed days had the following vertical profile: The $0^{\circ} \mathrm{C}$ isotherm was below $3.0 \mathrm{~km}$, the $-20^{\circ} \mathrm{C}$ around $6.0 \mathrm{~km}$, the $-40^{\circ} \mathrm{C}$ around $8.0 \mathrm{~km}$ and the tropopause between 10.0 and $11.0 \mathrm{~km}$. Analysing the lightning activity throughout those days, it is interesting to note that there is activity in the LMA only when radar reflectivity $>12 \mathrm{dBZ}$ is reported above the $-40^{\circ} \mathrm{C}$ isotherm height (around $8.0 \mathrm{~km}$ ). Besides, radar reflectivity $>35 \mathrm{dBZ}$ is above the $-20^{\circ} \mathrm{C}$ isotherm height, indicating sufficient conditions for electrification. On the analysed days, the TOP-35 radar product (maximum height of $35 \mathrm{dBZ}$ ) hardly reached $7 \mathrm{~km}$,

The bulk of the LMA sources were distributed around $4 \mathrm{~km}$, just above the melting layer. In fact, the melting layer can be inferred in Fig. 6, where the "bright band" radar signal is visible and occurs in the layer where snowflakes are melting into rain [13].

Lightning occurrence displays a marked seasonality in Catalonia, with about $50 \%$ of the activity taking place in July and August, according to the last ten years average. $83 \%$ of lightning occur from June to September, and 94\% from May to October. The months of the present case studies, April and November, account $3.7 \%$ and $1.3 \%$ of the annual activity, respectively. Therefore, the storms analysed here can be considered "out of season". Regarding risk assessment, even if downward lightning to wind turbines can be more common in relation to deep convective situations, results suggest that "out of season" thunderstorms, showing limited vertical extent, may also be a threat to wind turbines.

\section{ACKNOWLEDGMENT}

This work was supported by research grants from the Spanish Ministry of Economy and Competitiveness (MINECO) and the European Regional Development Fund (FEDER): (MINECO) AYA2011-29936-C05-04; (MINECO/FEDER) ESP2013- 48032-C5-3-R and (MINECO/FEDER) ESP201569909-C5-5-R; as well as by by Fulgura S.L., the Meteorological Service of Catalonia and the Autonomous Government of Catalonia, under the framework of the Industrial Doctorate Programme.

\section{REFERENCES}

[1] O. van der Velde, J. Montanyà, B. Rison, G. Aulich, N. Pineda, S. Soula, D. Romero, R. Rico, V. Reglero, "First Results of the Lightning Mapping Array in the Ebro Delta," American Geophysical Union Fall Meeting, San Francisco, USA, 5-9 Dec, 2011.

[2] J. Montanyà, O. van der Velde, and E. R. Williams, "Lightning discharges produced by wind turbines,"J. Geophys. Res. Atmos., 119, pp. 14551462, 2014.

[3] W. Rison, K. Cummins, R. Thomas, P. Krehbiel, D. Rodeheffer, M. Quick, and J. Myers, "Observations of corona discharges from wind turbines," in proc of International Conference on Lightning and Static Electricity, Toulouse, France, 2015.

[4] W. Rison, R. Thomas, P. Krehbiel, D. Rodeheffer, K. Cummins, M. Quick, J. Myers, T. Warner, M. Saba, C Schumann, W. Lyons, T. Samaras, P. Samaras, C. Young, S. Cummer and G. Lu, "Lightning Mapping and Electric Field Observations of Naturally Induced Upward Positive Leaders from Wind Turbines, “ICAE 2014, 2014.

[5] W. Rison, R.J. Thomas, P.R. Krehbiel, T. Hamlin, and J. Harlin, “A GPSbased three-dimensional lightning mapping system: Initial observations in central New Mexico,” J. Geophys. Res., 26, pp. 3573-3576 1999.

[6] Betz, H.-D., K. Schmidt, P. Oettinger, and M. Wirz, "Lightning detection with 3-D discrimination of intracloud and cloud-to ground discharges," Geophys. Res. Lett., 31, L11108, doi:10.1029/2004GL019821, 2004.

[7] Argemí O., A. Belmonte, X. Fàbregas, N. Pineda, T. Rigo, J. Bech: Wind turbine impact evolution and beam blockage analysis on the weather radar network of the Meteorological Service of Catalonia, 7th European Conference on radar in Meteorology and Hydrology (ERAD) Toulouse, France, 25th to 29th June 2012.

http://www.meteo.fr/cic/meetings/2012/ERAD/extended_abs/NET_013_ ext_abs.pdf.

[8] Mazur, V.,"Physical processes during development of lightning flashes," Comptes Rendus Phys., 3, pp. 1393-1409, 2002.

[9] van der Velde, O. A., and J. Montanyà (2013), "Asymmetries in bidirectional leader development of lightning flashes," J. Geophys. Res. Atmos., 118, 13,504-13,519, doi:10.1002/2013JD020257.

[10] J. Montanyà, Fabró, F., van der Velde, O., March, V., Williams, E. R., Pineda, N., Romero, D., Solà, G., and Freijo, M. "Global Distribution of Winter Lightning: a threat to wind turbines and aircraft," Nat. Hazards Earth Syst. Sci. Discuss., doi:10.5194/nhess-2015-302, in review, 2016. 
Preprint of the Int. Conf. on Lightning Protection (ICLP 2016)

[11] van der Velde, O. A., J. Montanyà, S. Soula, N. Pineda, and J. Mlynarczyk (2014), "Bidirectional leader development in sprite-producing positive cloud-to-ground flashes: Origins and characteristics of positive and negative leaders," J. Geophys. Res. Atmos., 119, 12,755-12,779, doi:10.1002/2013JD021291.

[12] Deierling, W., W. A. Petersen, J. Latham, S. Ellis, and H. J. Christian (2008), The relationship between lightning activity and ice fluxes in thunderstorms, J. Geophys. Res., 113, D15210, doi:10.1029/2007JD009700.

[13] Fabry, F., Zawadzki, I., 1995. Long-Term Radar Observations of the Melting Layer of Precipitation and Their Interpretation. Journal of the Atmospheric Sciences, 52(7): 838-851 